\title{
IMPLEMENTASI METODE PEMBELAJARAN PENDIDIKAN AGAMA ISLAM (PAI) DI SEKOLAH MENENGAH ATAS NEGERI (SMA) 11 BANDUNG
}

\author{
IMPLEMENTATION OF ISLAMIC RELIGIOUS EDUCATION (PAI) LEARNING \\ METHODS AT PUBLIC SENIOR HIGH SCHOOL (SMAN) 11 OF BANDUNG
}

\author{
Lisa'diyah Ma'rifataini \\ Pusat Penelitian dan Pengembangan Kementerian Agama RI. \\ Jl. M.H. Thamrin No. 6, Jakarta Pusat \\ email: lisa.litbang@gmail.com
}

Naskah Diterima: 6 April 2018; Direvisi: 20 April 2018; Disetujui: 29 April 2018

\begin{abstract}
The Ministry of Religious Affairs in cooperation with ACDP has facilitated 40 PAI teachers to attend a training of Islamic Religious Education learning methods in Oxford, English. Among the learning methods implemented in Oxford are Market Place Activites, Expert Group, and Group Investigation methods. Such learning methods are not yet familiar to PAI teachers in Indonesia, so then a question arises as to how the implementation of such PAI methods after the said training. This research deployed experimental method. The results showed that the Market Place Activities, Expert Group, and Group Investigation learning methods had been implemented by PAI Teachers of SMAN 11 of Bandung upon their PAI learning activities; The students responded positively to those three implemented methods, according to the students, the learning materials taught through Market Place Activities method make them easily to understand, so did they when taught through Expert Group and Group Investigation. The result of significant test of those three methods is 0,008, it shows that these three methods, based on the students' achievement on pre-test and posttest, improved and there was no difference between these three learning methods. Supporting factors in the application of these three methods are the teachers' masteries thereof, the students accustomed to receive learning materials through application of various learning methods, the school management encourages each teacher to develop various learning methods, the school's infrastructures, and the supporting learning resources and learning media in implementing such learning methods.
\end{abstract}

Keywords: Expert group; Group investigation; Market place activities; Method learning

\begin{abstract}
Abstrak
Kementerian Agama bekerjasama dengan ACDP telah memberikan fasilitas 40 guru pendidikan agama Islam mengikuti pelatihan metode pembelajaran PAI di Oxford Inggris. Diantara metode pembelajaran yang diimplementasikan di Oxford adalah metode Market Place Activites, Expert Group, dan Group Investigation. Metode-metode pembelajaran tersebut masih belum familliar dikalangan guru PAI di Indonesia, sehingga timbul pertanyaan bagaimana implementasi tiga metode PAI pasca pelatihan. Penelitian ini menggunakan metode eksperimen. Hasil penelitian menunjukkan metode Market Place Activities, Expert Group, dan Group Investigation pada pembelajaran PAI telah diimplementasikan oleh Guru PAI SMA Negeri 11 Bandung; Respon siswa terhadap tiga metode mengatakan baik, materi dengan metode Market Place Actifitties pada umumnya siswa mengatakan sangat mudah, Expet Group dan Group Invergation siswa mengatakan mudah. Hasil uji signifikansi dari tiga metode tersebut sebesar 0,008, ini menunjukkan ketiga metode berdasarkan hasil pre tes dan post tes prestasi siswa meningkat dan tidak ada perbedaan diantara ketiga metode pembelajaran tersebut. Faktor pendukung dalam penerapan ketiga metode tersebut adalah Guru menguasai metode pembelajaran, siswa terbiasa menerima pembelajaran melalui penerapan berbagai metode pembelajaran, manajemen sekolah mendorong setiap guru
\end{abstract}


untuk mengembangkan berbagai metode pembelajaran, sarana prasarana, sumber belajar dan media pembelajaran mendukung dalam mengimplementasikan metode pembelajaran tersebut.

Kata kunci: Expert group; Group investigation; Market place activities; Metode pembelajaran

\section{PENDAHULUAN}

Pemerintah melalui Kementerian Pendidikan dan Kebudayaan (Kemendikbud) mengambil keputusan untuk mengubah kurikulum pendidikan dari Kurikulum Tingkat Satuan Pendidikan (KTSP) menjadi Kurikulum 2013. Kurikulum ini berlaku mulai tahun 2014.

Dalam kurikulum 2013, ada perubahan yang fundamental khususnya dalam Pendidikan Agama Islam (PAI) yang diterapkan yaitu Pertama, nama mata pelajaran PAI menjadi pendidikan agama dan budi pekerti. Kedua, isi mata pelajaran pendidikan agama hanya mengajarkan agama saja tetapi juga mengajarkan aspek afektif yang mencakup nilai-nilai karakter, disiplin, menghargai, toleransi, demokrasi, dan juga pengembangan kognitif. Ketiga, konsekueansi dari pengembangan isi tersebut adalah jumlah jam mengajar akan dilipatgandakan dari 2 jam menjadi 4 jam mata pelajaran perminggu. Keempat, standar kompetensi lulusan juga diperluas tidak hanya mencakup domain spiritual tetapi juga sosial, ilmu pengetahuan dan keahlian, maka dibutuhkan guru-guru yang berkompeten.

Dengan perubahan kurikulum tersebut, berbagai masalah muncul terkait dengan implementasi kurikulum pada guru PAI. Dalam kurikulum 2013, guru dituntut untuk secara profesional merancang pembelajaran efektif dan bermakna, mengorganisasikan pembelajaran, memilih pendekatan pembelajaran yang tepat, menentukan prosedur pembelajaran dan pembentukan kompetensi secara efektif, serta menetapkan kriteria keberhasilan. Sementara itu masih guru PAI yang belum memahami tentang kurikulum 2013 dan pemerintah pun belum banyak memberikan pelatihan terkait kurikulum 2013, sehingga banyak guru yang masih bingung bagaimana mengimplentasikan kurikulum 2013, bagaimana pengembangan kurikulum tersebut, metode pembelajaran, metode penilaian, dan sebagainya.

Selain masalah kompetensi guru PAI dalam implementasi kurikulum 2013, masalah lain yang sering dipertanyakan adalah masalah kompetensi mengajar guru. Kompetensi guru, seperti dinyatakan dalam PMA Nomor 16 Tahun 2010 (Pasal 16), guru harus memiliki kompetensi pedagogik, kepribadian, sosial, profesional, dan kepemimpinan. Kompetensi yang selama ini hanya dipahami saja, harusnya dipahami secara mendalam dan dilaksanakan dalam proses pembelajaran. Di samping itu, guru harus selalu update informasi, memperbarui pengetahuan dan kompetensi yang dimiliki agar tidak ketinggalan. Sebab bagaimanapun, ilmu pengetahuan juga bisa mengalami expired, kadaluwarsa, termasuk juga metodologi mengajarnya. Dengan semakin meningkatnya kualifikasi akademik dan kompetensi GPAI, ke depan pembelajaran PAI bisa menjadi lebih efektif, menyenangkan, dan siap bersaing dengan mata pelajaran umum yang lain.

Berbagai upaya telah dilakukan pemerintah untuk meningkatkan kompetensi guru Pendidikan Agama Islam (PAI). Dalam implementasikurikulum 2013, misalnya,salah satunya adalah memberikan pelatihan bagi guru PAI. Pada tahun 2015 ini, Kementerian Agama, baik Pusat maupun Daerah, memberikan Bimtek Kurikulum 2013 PAI bagi Guru PAI yang belum mengikutinya. Sedangkan bagi yang sudah mengikuti Bimtek Kurikulum 2013 PAI akan diberikan pendampingan.

Upaya lain yang sudah dilakukan pemerintah adalah memberikan pelatihan bagi guru yang berprestasi. Dalam hal ini Kementerian Agama (Direktorat Pendidikan Agama Islam) bekerjasama dengan $\mathrm{ACDP}^{1}$ telah memberikan fasilitas kepada 40 guru pendidikan agama Islam mengikuti pelatihan metodologi pembelajaran PAI di Oxford Inggris. Diantara metode pembelajaran yang diajarkan adalah Metode Market Place Activity, Expert Group, dan metode Group Investigation.

${ }^{1} A C D P$ singkatan dari Aanalytical and Capacity Development Partnership, yaitu lembaga yang memberikan fasilitas untuk mempromosikan dialog kebijakan dan reformasi kelembagaan dalam sector pendidikan di Indonesia. 
Program pelatihan tersebut, selain untuk meningkatkan kompetensi mengajar guru-guru tersebut, diharapkan mereka dapat menjadi trainer $(\mathrm{TOT})^{2}$ nasioanal dalam metodologi pembelajaran berbasis project dan Problim Solving pada PAI di Sekolah. Salah satu tujuan dari TOT tersebut diantaranya adalah untuk memperbaiki kompetensi guru PAI dalam metodologi pembelajaran pendidikan agama dan Budi Pekerti, (metode pembelajaran menggunakan pendekatan berbasis Project dan Problim Solving yang berkaitan dengan pendekatan metode pembelajaran aktif kurikulum 2013). ${ }^{3}$

Metode pembelajaran yang diajarkan di Oxford tersebut masih belum familliar dikalangan para guru PAI di Indonesia, sehingga berbagai pertanyaan muncul, bagaimana implementasi metode Market Place Activity, Expert Group, dan Group Investigation pada pembelajaran PAI, bagaimana respon siswa terhadap metode pembelajaran tersebut, apakah ketiga metode tersebut dapat meningkatkan prestasi siswa, dan apa pendukung dan kendala yang dihadapi guru PAI dalam mengimplementasikan metode tersebut.

Manfaat hasil penelitian ini adalah sebagai bahan masukan Direktorat PAIS Dirjen PENDIS dalam pengambilan kebijakan terkait peningkatan kompetensi Guru Pendidikan Agama Islam (GPAI) dalam mengajar, juga diharapkan sebagai bahan masukan dalam meningkatkan mutu pendidikan dalam suatu pembelajaran oleh guru-guru dalam bidang ilmu khususnya pendidikan Agama Islam dengan menggunakan metode Market Place Activities, Expert Group, dan Group Investigation.

Implementasi merupakan penyediaan sarana untuk melaksanakan sesuatu yang menimbulkan dampak atau akibat terhadap sesuatu. Sesuatu tersebut dilakukan untuk menimbulkan dampak atau akibat itu dapat berupa undang-undang, Peraturan Pemerintah,

${ }^{2}$ TOT singkatan dari Training Of Trainer, yaitu pelatihan ketrampilan melatih dilakukan dalam rangka memberikan kemampuan penguasaan materi kepada para trainer.

${ }^{3} A C D P, \quad$ Terms Of Reference ToT for NATIONAL Trainers on Teaching Methodology of Islamic Religius Education. Implementing patner Directorate of Islamic Education, Directorate General of Islamic Education, Ministry of Religious Affairs keputusan peradilan dan kebijakan yang dibuat oleh lembaga-lembaga pemerintah dalam kehidupan kenegaraan. ${ }^{4}$

Nurdin dan Usman mengemukakan implementasi adalah bermuara pada aktivitas, aksi, tindakan, atau adanya mekanisme suatu sistem. Implementasi bukan sekedar aktivitas, tetapi suatu kegiatan yang terencana dan untuk mencapaitujuan kegiatan. ${ }^{5}$ Pengertian implementasi yang dikemukakan, dapat dikatakan bahwa implementasi adalah bukan sekedar aktivitas, tetapi suatu kegiatan yang terencana dan dilakukan secara sungguhsungguh berdasarkan acuan norma tertentu untuk mencapai tujuan kegiatan. Oleh karena itu implementasi tidak berdiri sendiri tetapi dipengaruhi oleh objek berikutnya.

Pendekatan kedua, Nurdin dan Usman menekankan pada fase penyempurnaan. Kata proses dalam pendekatan ini lebih menekankan pada interaksi antara pengembang dan guru (praktisi pendidikan). Pengembang melakukan pemeriksaan pada program baru yang direncanakan, sumber-sumber baru, dan memasukan isi/materi baru ke program yang sudah ada berdasarkan hasil uji coba di lapangan dan pengalaman-pengalaman guru. Interaksi antara pengembang dan guru terjadi dalam rangka penyempurnaan program, pengembang mengadakan lokakarya atau diskusi-diskusi dengan guru-guru untuk memperoleh masukan. Implementasi dianggap selesai manakala proses penyempurnaan program baru dipandang sudah lengkap.Sedangkan pendekatan ketiga, Nurdin dan Usman memandang implementasi sebagai bagian dari program kurikulum. Proses implementasi dilakukan dengan mengikuti perkembangan dan megadopsi programprogram yang sudah direncanakan dan sudah diorganisasikan dalam bentuk kurikulum desain (dokumentasi). ${ }^{6}$

Guntur Setiawan dalam bukunya yang berjudul Implementasi Dalam Birokrasi Pembangunan mengemukakan implementasi adalah perluasan aktivitas yang saling

\footnotetext{
${ }^{4}$ (http://rimaru.web.id/pengertian - implementasi menurut - beberapa-ahli/). Diakses 29 Agustus 2016.

${ }^{5}$ Usman, Nurdin,. 2002. Konteks Implementasi Berbasis Kurikulum. Jakarta:PT. Raja Grafindo Persada. Hal. 70

${ }^{6}$ Ibid.
} 
menyesuaikan proses interaksi antara tujuan dan tindakan untuk mencapainya serta memerlukan jaringan pelaksana, birokrasi yang efektif. $^{7} \quad$ Pengertian implementasi yang dikemukakan di atas, dapat dikatakan bahwa implementasi yaitu merupakan proses untuk melaksanakan ide, proses atau seperangkat aktivitas baru dengan harapan orang lain dapat menerima dan melakukan penyesuaian dalam tubuh birokrasi demi terciptanya suatu tujuan yang bisa tercapai dengan jaringan pelaksana yang bisa dipercaya.

Implementasi merupakan tindakantindakan untuk mencapai tujuan yang telah digariskan dalam keputusan kebijakan. Tindakan tersebut dilakukan baik oleh individu, pejabat pemerintah ataupun swasta. Dunn mengistilahkannya implementasi secara lebih khusus, menyebutnya dengan istilah implementasi kebijakan dalam bukunya yang berjudul Analisis Kebijakan Publik. Menurutnya implementasi kebijakan (Policy Implementation) adalah pelaksanaan pengendalian aksi-aksi kebijakan didalam kurun waktu tertentu. ${ }^{8}$

Dari berbagai uraian diatas, definisi implementasi dalam penelitian ini adalah kemampuan menggunakan materi yang telah dipelajari kedalam situasi kongkret atau nyata mencakup aktivitas pengajaran dalam bentuk interaktif antara guru dan siswa dibawah naungan sekolah.

\section{Metode Pembelajaran}

Metode adalah cara yang digunakan untuk mengimplementasikan rencana yang sudah disusun dalam kegiatan nyata agar tujuan yang telah disusun tercapai secara optimal.Ini berarti metode digunakan untuk merealisasikan proses belajar mengajar yang telah ditetapkan.Menurut Abdurrahman Ginting, metode pembelajaran dapat diartikan cara atau pola yang khas dalam memanfaatkan berbagai prinsip dasar pendidikan serta berbagai teknik dan sumber daya terkait

\footnotetext{
${ }^{7}$ Guntur Setiawan., 2004. Implementasi Dalam Birokrasi Pembangungan. Jakarta: Cipta Dunia. Hal.39

${ }^{8}$ Dikutip dari artikel ejournal Emma Ratna Sari, tentang Implementasi kebijakan pelayanan pubik melalui ejournal.an.fisipunmul.ac.id/.../artikel_ejournal\%20emma\%20
}

lainnya agar terjadi proses pembelajaran pada diri pembelajar. ${ }^{9}$

Dengan kata lain metode pembelajaran adalah teknik penyajian yang dikuasai oleh seorang guru untuk menyajikan materi pelajaran kepada murid di dalam kelas baik secara individual atau secara kelompok agar materi pelajaran dapat diserap, dipahami dan dimanfaatkan oleh murid dengan baik. Dalam kenyataannya, cara atau metode pembelajaran yang digunakan untuk menyampaikan informasi berbeda dengan cara yang ditempuh untuk memantapkan siswa dalam menguasai pengetahuan, ketrampilan dan sikap. ${ }^{10}$ Khusus metode pembelajaran di kelas, efektifitas metode dipengaruhi oleh faktor tujuan, faktor siswa, faktor situasi dan faktor guru itu sendiri. Dengan demikian metode dalam rangkaian sistem pembelajaran memegang peran yang sangat penting, karena keberhasilan pembelajaran sangat tergantung pada cara guru dalam menggunakan metode pembelajaran.

\section{Ciri-Ciri Metode Pembelajaran yang Baik}

Banyak metode yang bisa dipilih oleh seorang guru dalam kegiatan belajar mengajar. Oleh karena itu setiap guru yang akan mengajar diharapkan untuk memilih metode yang baik. Karena baik dan tidaknya suatu metode yang akan digunakan dalam proses belajar mengajar terletak pada ketepatan memilih suatu metode sesuai dengan tuntutan proses belajar mengajar.

Penggunaan suatu metode pembelajaran yang baik harus memperhatikan beberapa hal berikut: ${ }^{11}$

a. Metode yang digunakan dapat membangkitkan motif, minat atau gairah belajar murid.

b. Metode yang digunakan dapat menjamin perkembangan kegiatankepribadian murid.

\footnotetext{
${ }^{9}$ Abdurrahman Ginting, Esensi Praktis Belajar dan Pembelajaran (Bandung: Humaniora, 2008), 42.3

${ }^{10}$ Wina Sanjaya, Strategi Pembelajaran Berorientasi Standar Proses Pendidikan (Jakarta: Kencana Prenada Media Group, 2008),147.2

${ }^{11}$ Ahmadi, Abu. Prastya, Joko T. 2000. Strategi Belajar Mengajar. Bandung: CV Pustaka Setia, diakses http://www.kompasiana.com/faizatunnimah/metodeguru-dalam-mengajar-dapat-meningkatkan-motivasibelajar-siswa.
} 
c. Metode yang digunakan dapat memberikan kesempatan kepada murid untuk mewujudkan hasil karya.

d. Metode yang digunakan dapat merangsang keinginan siswa untuk belajar lebih lanjut, melakukan eksplorasi dan inovasi.

e. Metode yang digunakan dapat mendidik murid dalam teknik belajar sendiri dan cara memperoleh ilmu pengetahuan melalui usaha pribadi.

f. Metode yang digunakan dapat meniadakan penyajian yang bersifat verbalitas dan menggantinya dengan pengalaman atau situasi yang nyata dan bertujuan.

g. Metode yang digunakan dapat menanamkan dan mengembangkan nilai-nilai serta sikapsikap utama yang diharapkan dalam kebiasaan cara bekerja yang baik dalam kehidupan sehari-hari.

\section{Metode Market Place Activities}

Market Place Activities adalah metode pembelajaran berupa kegiatan pasar, dimana siswa dapat melakukan aktivitas jual beli informasi. Terdapat kelompok siswa pemilik informasi untuk dijual kepada kelompok lain dan kelompok siswa yang membeli informasi. Informasi yang diperjualbelikan adalah materi yang dipelajari pada hari itu. Tanggung jawab untuk mencari informasi secara individual dan mempu mempromosikan hasil kajiannya. Melalui metode ini siswa diberi tanggung jawab untuk membuat perencanaan dan pengembangan pembelajaran mereka tentang suatu pokok bahasan. Metode ini sangat baik untuk mengembangkan rasa kemandirian dan kepercayaan diri, membangun kerjasama, keterampilan kelompok, dan umpan balik.

Kegunaan metode ini adalah siswa merasa bertanggung jawab untuk mencari informasi secara individual, belajar memberanikan diri untuk mempromosikan hasil kajiannya, belajar mendengarkan orang lain yang sedang berbicara. ${ }^{12}$

\section{Metode Expert Group}

Metode Expert Group adalah metode pembelajaran melalui pembentukan kelompok peserta didik yang berperan sebagai ahli dalam materi yang akan dibahas. Metode ini

${ }^{12}$ Ibid, hal 145 dilakukan melalui system kerja kelompok yang heterogen, dengan memanfaatkan hal-hal yang positif antar anggota kelompok untuk menumbuhkan kerja sama, saling membantu, dan saling mendorong untuk menyelesaikan persoalan tertentu. Kemampuan bekerjasama dengan kelompok merupakan kemampuan yang penting bagi peserta didik untuk dilatih dalam memecahkan berbagai persoalan yang mereka hadapi. Metode ini juga melibatkan partisipasi aktif peserta didik dalam proses pembelajaran, perlunya pengembangan peserta didik belajar mandiri, dan perlunya peserta didik memiliki kemampuan untuk mengembangkan pengetahuannya sendiri.

Metode expert group ini dikembangkan berdasarkan pandangan filosofis sebagai berikut: a) Mengembangkan pengalaman belajar yang memberikan kesempatan luas bagi peserta didik untuk menguasai kompetensi yang diperlukan. b) Memberi kesempatan kepada peserta didik untuk mengembangkan potensi dirinya menjadi kemampuan berfikir rasional. c) Mengembangkan kemampuan intelektual peserta didik. d) Meningkatkan kemampuan berkomunikasi, sikap sosial, kepedulian, dan berpartisipasi untuk membangun kehidupan masyarakat.

Sedangkan landasan pedagogisnya adalah sebagai wahana kemandirian peserta didik sesuai dengan perkembangan psikologisnya dan mendapatkan perlakuan sesuai dengan perkembangannya.

Kegunaan metode ini adalah melatih tanggungjawab dalam kelompok, mengembangkan sikap disiplin, focus dalam pembelajaran, melatih keberanian, melatih dalam berfikir kritis dan logis, melibatkan seluruh peserta didik, membangun kreativitas, kerjasama dalam kelompok, saling memberikan motivasi, pembagian tugas sesuai kemampuan, melatih kemandirian, dan menghargai pendapat. ${ }^{13}$

\section{Metode Group Investigation}

Metode Group Investigation adalah salah satu bentuk metode pembelajaran kooperatif

${ }^{13}$ Direktorat Pendidikan Agama Islam, Direktorat Jenderal Pendidikan Islam Kementerian Agama RI, 2015, Modul Metode Pembelajaran, Bimbingan Teknis Pembelajaran Pendidikan Agama Islam dan Budi Pekerti berbasis ISRA, hal.73 
yang menekankan pada partisipasi dan aktivitas peserta didik untuk mencari sendiri materi (informasi) pelajaran yang akan dipelajari melalui bahan-bahan yang tersedia, misalnya dari buku pelajaran atau peserta didik dapat mencari melalui internet. Metode ini dipakai untuk materi yang memerlukan pemecahan masalah. Memecahkan permasalahan secara berkelompok dapat meningkatkan keterlibatan paserta didik.

Dalam investigasi kelompok, siswa membentuk kelompok seminat yang merencanakan dan melaksanakan suatu investigasi serta mengintegrasikan hasilnya untuk dilaporkan di kelas. Tugas guru adalah membuat siswa menyadari bahwa banyak informasi yang berguana dari hasil investigasi tersebut.

Kegunaan metode ini adalah: 1) membantu peserta didik untuk melakukan investigasi terhadap suatu topik secara sistematis dan analitik. Hal ini mempunyai implementasi yang positif terhadap pengembangan keterampilan penemuan dan membantu mencapai tujuan. 2) pemahaman secara mendalam terhadap suatu topik yang dilakukan melalui investigasi. 3) melatih peserta didik untuk bekerja secara kooperatif dalam memecahkan suatu masalah. Dengan adanya kegiatan tersebut, peserta didik dibekalai keterampilan hidup (life skill) yang berharga dalam kehidupan bermasyarakat. Jadi guru menerapkan metode pembelajaran penyidikan kelompok dapat mencapai tiga hal, yaitu dapat belajar dengan penemuan, belajar isi, dan belajar untuk bekerja secara kooperatif. 4) menumbuhkembangkan keberanian peserta didik dalam bertanya dan berpendapat. 5) peserta didik akan lebih berani bertanya apabila pertanyaan telah dipahami terlebih dahulu. ${ }^{14}$

\section{METODE PENELITIAN}

Penelitian ini menggunakan pendekatan kuantitative dengan jenis penelitian eksperimen karena tujuan dari penelitian eksperimen menurut Desi Sutedi adalah untuk menguji efektifitas dan efisiensi dari suatu pendekatan pembelajaran. Penelitian ini dibatasi pada metode pembelajaran Market Place Activity, Expert Group, dan Group Investigation, karena metode ini adalah metode

\footnotetext{
${ }^{14}$ Ibid, hal 197
}

yang diajarkan waktu pelatihan di Oxford Ingeris. Teknik analisis penelitian ini menggunakan statistik deskriptif presentasi dan inferensial untuk mencari signifikansi perbedaan peningkatan prestasi siswa pada 3 metode pembelajaran PAI. Lokasi penelitian ini adalah sekolah yang dijadikan percontohan untuk metode pembelajaran Market Place Activity, Expert Group, dan Group Investigation hasil dari pelatihan di Oxford, oleh sebab itu penelitian dilakukan di SMA Negeri 11 Bandung Jawa Barat. Responden dalam penilitian ini adalah Kepala Sekolah, Waka Kurikulum, Pengawas PAI, Guru PAI, dan siswa yang sudah mendapatkan metode pembelajaran PAI dari Oxford dan diajar oleh guru yang telah mendapatkan pelatihan.

\section{HASIL DAN PEMBAHASAN}

\section{Implementasi Metode Pembelajaran}

Kegiatan pembelajaran dunia pendidikan yang tertuang dalam Rencana Pelaksanaan Pembelajaran sesuai Permendiknas No. 41 Tahun 2007 tentang Standar Proses Pembelajaran, terdiri dari tiga kegiatan yaitu kegiatan Pendahuluan, kegiatan Inti yang mencakup Eksplorasi, Elaborasi, dan Konfirmasi, dan kegiatan Penutup. ${ }^{15}$

Kegiatan pendahuluan merupakan kegiatan awal dalam suatu pertemuan pembelajaran yang ditujukan untuk membangkitkan motivasi dan memfokuskan perhatian peserta didik untuk berpartisipasi aktif dalam proses pembelajaran.

Kegiatan inti merupakan proses pembelajaran untuk mencapai kompetensi dasar. Kegiatan pembelajaran dilakukan secara interaktif, inspiratif, menyenangkan, menantang, memotivasi peserta didik untuk berpartisipasi aktif, serta memberikan ruang yang cukup bagi prakarsa, kreativitas, dan kemandirian sesuai dengan bakat, minat, dan perkembangan fisik serta psikologis peserta didik. Kegiatan ini dilakukan secara sistematis dan sistemik melalui proses eksplorasi, elaborasi, dan konfirmasi.

Kegiatan penutup merupakan kegiatan yang dilakukan untuk mengakhiri aktivitas

${ }^{15}$ Lampiran Permendiknas Nomor 41 Tahun 2007 Tanggal 23 November 2007 tentang Standar Poses untuk Satuan Pendidikan Dasar dan Menengah 
pembelajaran yang dapat dilakukan dalam bentuk rangkuman atau kesimpulan, penilaian dan refleksi, umpan balik, dan tindaklanjut.

Implementasi metode pembelajaran Maket Place Activities, Expert Group, dan Group Investigation, telah di implementasikan di SMA Negeri 11 Bandung.

\section{Implementasi pembelajaran Market Place Activities}

Pada pembelajaran Market Place Activities, sebelum proses belajar mengajar di mulai dilakukan persiapan, dimana pertama kali melakukan kegiatan membaca al-Quran, berdo'a dipimpin oleh salah satu peserta didik, guru memberikan motivasi kepada peserta didik sehingga mereka siap menerima pembelajaran dan menjelaskan kegiatan pembelajaran yang akan dilakukan. Sebelumnya menyiapkan alat dan bahan yang diperlukan dalam metode ini seperti kertas plano, spidol kecil berwarna, kertas post-it, lakban kertas, gunting, cutter.

Media bantuan Market Place Activities yang diperlukan adalah Laptop, Projector, Power Point materi ajar, Video pengantar, Copy Materi Ajar dan Alat jual beli (kertas post-it) juga dipersiapkan sebelum pembelajaran. Juga media bantuan lain yang perlu dipersiapkan Lembar Kerja yang akan dipakai pada saat pelaksanaan metode seperti lembar kerja penjual, lembar kerja pembeli serta lembar kerja pre-test dan post-test.

Dalam proses pembelajaran, kelas di dibentuk menjadi grup grup kecil berjumlah tidak lebih dari 5 orang, semua peserta didik dalam satu grup harus berhadapan, pembentukan grup bersifat heterogen, kemudian guru melakukan pre-test.

Pada kegiatan inti, setiap kelompok mendapat ringkasan sub materi, sub materi ini berbeda antara satu kelompok dengan kelompok lainnya, Barang yang dijual adalah informasi mengenai sub materi aja. Persiapannya adalah dengan cara memahami materi tersebut semaksimal mungkin, kemudian barang yang dijual adalah sub materi dari kelompok masing-masing, semua kelompok melakukan transaksi karena pasarnya terbuka.

Proses transaksi dalam jual beli materi yaitu dalam satu kelompok terbagi menjadi penjual dan pembeli, para penjual menyiapkan diri untuk menjual barangnya (informasi materi ajar) dengan cara menjawab pertanyaan dari pembeli kelompom lain, para pembeli melakukan pembelian dengan cara bertanya kepada kelompok lain, bila telah selesai bertanya, pembeli harus memberikan penilaian kepuasan jawaban tersebut. Waktu transaksi masing-masing kelompok adalah antara $5 \mathrm{~s}, \mathrm{~d} 8$ menit per putaran dan bisa dilakukan dalam beberapa kali putaran tergantung waktu yang tersedia. Cara pelaporannya: setiap kelompok melaporkan seberapa banyak barang yang bisa dibeli dan berapa yang terjual, dengan mencantumkan jumlah pertanyaan dan jawaban yang terkumpul serta bagaimana tingkat kepuasannya.

Penilaian diberikan dengan menghitung jumlah pertanyaan yang diberikan + jumlah jawaban + tingkat kepuasan. Refleksi dilakukan untuk mempertajam materi serta membahas hal-hal yang menjadi focus perhatian dalam pembelajaran. ${ }^{16}$

Pada kegiatan penutup, guru memberikan penguatan pada materi-materi yang tidak mendapat pembahasan dan materi-materi yang dianggap menyimpang pembahasannya. Menyampaikan kesimpulan dari pembelajaran yang telah disampaikan, kegiatan ini bisa dilakukan oleh siswa atau gabungan antara siswa dan guru, dan menyampaikan kilasan materi yang akan disampaikan pada pertemuan berikutnya. Terakhir untuk mendapatkan nilai melakukan post-test.

\section{Implementasi pembelajaran Expert Group}

Dalam persiapan, pembelajaran Expert Group dilakukan melalui kegiatan-kegiatan seperti pada pembelajaran Market Place Activities yaitu membaca al-Quran, berdo'a dipimpin oleh salah satu peserta didik. Guru memberikan motivasi kepada peserta didik sehingga mereka siap menerima pembelajaran dan menjelaskan kegiatan pembelajaran yang akan dilakukan. Sedangkan persiapan lain yaitu penyiapan alat dan bahan yang diperlukan dalam metode ini diantaranya; kertas plano, spidol kecil berwarna, kertas post-it, lakban kertas, gunting, cutter, juga

${ }^{16}$ Observasi pembelajaran di kelas pada hari Rabu, 26 Oktober 2016 pengajar Guru PAI Atik Tapipim SMA Negeri 11 Bandung. 
media bantuan yang meliputi Laptop, Projector, PPt materi ajar, video pengantar, copy materi ajar.

Dalam kegiatan pendahuluan, guru memberi motivasi siswa dalam bentuk penayangan video atau gambar yang memperlihatkan keunggulan siapapun yang menguasai materi bersangkutan. Pre-Test diberikan dalam bentuk PPt yang ditayangkan melalui projector, peserta didik mengisi pertanyaan-pertanyaan dalam lembar jawaban yang sudah disiapkan. Dalam pembagian kelompok, siswa cukup dibagi ke dalam 2 kelompok besar, kelompok ahli dan kelompok non ahli, kelompok ahli terdiri dari dua siswa per sub materi yang secara sengaja dipilih karena kelebihan pemahaman dalam materi.

Selanjutnya dalam kegiatan inti, dalam proses pembelajaran, kelompok ahli dikumpulkan untuk diberi materi dasar dan pengarahan. Kelopok ahli tampil ke depan masing-masing menjelaskan bagiannya (misalnya terdiri dari kelompok ahli fikih perekonomian, kelompok praktisi bank Islam, kelompok ahli asuransi Islam dan lain lain). Siswa non ahli menyampaikan pertanyaan, harus jelas ditujukan pada kelompok ahli yang mana. Kemudian kelompok ahli menjawab sesuai pertanyaannya, begitu seterusnya berulang-ulang. ${ }^{17}$

Pada kegiatan penutup, guru memberikan penguatan pada materi-materi yang tidak mendapat pembahasan dan materi-materi yang dianggap menyimpang pembahasannya. MGuru menyampaikan kesimpulan dari pembelajaran yang telah dilakukan, kegiatan ini bisa dilakukan oleh siswa atau gabungan antara siswa dan guru, guru juga menyampaikan kilasan materi yang akan disampaikan pada pertemuan berikutnya dan melalukan post-test.

\section{Implementasi Pembelajaran Group Investigation}

Dalam melakukan pembelajaran PAI dengan metode Group Investigation, SMA Negeri 11 Bandung pertama melakukan memberikan motivasi dalam bentuk menayangkan video atau gambar yang

${ }^{17}$ Observasi pembelajaran di kelas pada hari Jum at, 28 Oktober 2016 pengajar GuruPAI Atik Tapipim SMA Negeri 11 Bandung. memperlihatkan keunggulan siapapun yang menguasai materi bersangkutan, kemudian melakukan pre test. Pre-Test diberikan dalam bentuk PPt yang ditayangkan melalui projector, peserta didik mengisi pertanyaanpertanyaan dalam Lembar Jawaban yang sudah disiapkan. Siswa dibagi menjadi kelompok kecil yang terdiri dari maksimal 4 orang. Yang dipersiapkan oleh siswa adalah menyiapkan lembar kerja meliputi, LK Investigasi, LK Analisa Hasil Investigasi dan LJ Pre-Test dan Post-Test

Dalam proses pembelajaran, kelompok siswa diberi topic pembahasan tertentu, kemudian siswa menelusuri bahan bacaan (investigasi literature), melakukan investigasi lapangan, mempresentasikan hasil investigasi (pertemuan selanjutnya) dan menyimpulkan bersama.Menyimpulkan bersama (pertemuan selanjutnya)

Pada kegiatan penutup, guru memberikan penguatan pada materi-materi yang tidak mendapat pembahasan dan materi-materi yang dianggap menyimpang pembahasannya menyampaikan kesimpulan dari pembelajaran yang telah disampaikan, kegiatan ini bisa dilakukan oleh siswa atau gabungan antara siswa dan guru, menyampaikan kilasan materi yang akan disampaikan pada pertemuan berikutnya. Dan melakukan Post-Test ${ }^{18}$

Metode pembelajaran Market place activities adalah metode pembelajaran yang cocok disampaikan di awal pertemuan, untuk memperkenalkan konsep, memahami prosedur, mengenalkan istilah-istilah yang berkaitan dengan materi pembelajaran, sedangkan metode pembelajaran Expert Group dan Group Investigation sangat baik disampaikan pada pertemuan kedua atau ketiga dimana pada pertemuan tersebut diperlukan penguatanpenguatan terhadap materi pembelajaran.

\section{Respon siswa terhadap metode pembelajaran Market Place Activities, Expert Group dan Group Investigation}

Berdasarkan hasil observasi diketahui bahwa respon siswa SMA Negeri 11 Bandung sangat positif terhadap implementasi metode pembelajaran Market Place Activities, Respon

${ }^{18}$ Observasi pembelajaran di kelas pada hari selasa, 29 November 2016 pengajar GuruPAI Atik Tapipim SMA Negeri 11 Bandung. 
terhadap metode ini seluruh siswa (33 0rang atau $100 \%$ ) mengatakan bahwa guru Pendidikan Agama Islam yang telah mendapatkan pelatihan dari Oxford dan telah mengajarkan PAI dengan metode pembelajaran Market Place Activities;

Seluruh siswa (33 0rang atau 100\%) juga mengatakan bahwa ada perbedaan pembelajaran PAI di kelas sebelum dan sesudah guru pulang dari pelatihan di Oxford University Inggris, siswa mengatakan bahwa pembelajaran PAI di sekolah lebih menyenangkan dengan menggunakan metode pembelajaran Market Place Activities.

Siswa juga mengatakan bahwa metode pembelajaran Market Place Activities dapat membangkitkan semangat belajar, dapat menambah gairah belajar, dapat mengembangkan kegiatan kepribadian, memberikan kesempatan untuk mewujudkan hasikarya, dapat merangsang keinginan untuk belajar lebih lanjut, dapat melakukan eksplorasi dan inovasi, dapat menanamkan dan mengembangkan nilainilai yang diharapkan, dan siswa mengatakan bahwa metode pembelajaran Market Place Activities dapat menanamkan sikap-sikap utama yang diharapkan.

Kebanyakan siswa 94\% mengatakan bahwa penggunaan metode pembelajaran Market Place Activities terasa lebih mudah memahami materi, dan hanya $3 \%$ yang mengatakan sulit. 97\% mengatakan bahwa metode pembelajaran Market Place Activities menjadikannya lebih mampu menyampaikan pendapat di dalam kelas. Siswa 85\% mengatakan bahwa metode pembelajaran Market Place Activities dapat menumbuhkan kebiasaan cara bekerja yang baik dalam kehidupan sehari-hari. 61\% siswa mengatakan bahwa metode pembelajaran Market Place Activities dapat meniadakan penyajian yang bersifat verbalitas. Dan $82 \%$ siswa mengatakan bahwa metode pembelajaran Market Place Activities dapat mengganti pengalaman atau situasi yang nyata dan bertujuan.

Selanjutnya berdasarkan hasil observasi diketahui bahwa respon siswa SMA Negeri 11 Bandung sangat positif terhadap implementasi metode pembelajaran Expert Group seperti terlihat dalam uraian sebagai berikut

Seluruh siswa (33 orang atau 100\%) mengatakan bahwa guru Pendidikan Agama
Islam mengajarkan PAI dengan metode pembelajaran Expert Group, dan mengatakan bahwa ada perbedaan pembelajaran PAI di kelas sebelum dan sesudah guru pulang dari pelatihan di Oxford University Inggris. Siswa mengatakan bahwa pembelajaran PAI di sekolah lebih menyenangkan dengan menggunakan metode pembelajaran Expert Group.Dan mengatakan bahwa metode pembelajaran Expert Group dapat membangkitkan semangat belajar, dapat menambah gairah belajar; memberikan kesempatan untuk mewujudkan hasil karya, dapat merangsang keinginan untuk belajar lebih lanjut. Dapat melakukan eksplorasi dan inovasi: dapat menanamkan dan mengembangkan nilai-nilai yang diharapkan dan mengatakan bahwa metode pembelajaran Expert Group dapat menanamkan sikap-sikap utama yang diharapkan.

Kebanyakan siswa 94\% mengatakan bahwa penggunaan metode pembelajaran Expert Group terasa lebih mudah memahami materi, hanya 1 orang atau 3\% mengatakan sulit. 97\% siswa mengatakan bahwa melalui metode pembelajaran Expert Group menjadikannya lebih mampu menyampaikan pendapat di dalam kelas dan dapat menumbuhkan kebiasaan cara bekerja yang baik dalam kehidupan sehari-hari.

Selanjutnya berdasarkan hasil observasi juga diketahui bahwa respon siswa SMA Negeri 11 Bandung sangat positif terhadap implementasi metode pembelajaran Group Investigation seperti terlihat dalam uraian sebagai berikut:

Seluruh siswa (33 0rang atau 100\%) mengatakan bahwa guru Pendidikan Agama Islam mengajarkan PAI dengan metode pembelajaran Group Investigation. Siswa mengatakan bahwa ada perbedaan pembelajaran PAI di kelas sebelum dan sesudah guru pulang dari pelatihan di Oxford University; dan mengatakan bahwa pembelajaran PAI di sekolah lebih menyenangkan dengan menggunakan metode pembelajaran Group Investigation, karenamembangkitkan semangat belajar, dapat menambah gairah belajar, dapat mengembangkan kegiatan kepribadian, memberikan kesempatan untuk mewujudkan hasil karya, dapat melakukan 
eksplorasi dan inovasi, dan mengembangkan nilai-nilai yang diharapkan

Sedangkan siswa 94\% mengatakan bahwa penggunaan metode pembelajaran Group Investigation terasa lebih mudah untuk memahami materi, hanya 3\% mengatakan sulit. Selanjutnya $97 \%$ siswa mengatakan bahwa metode pembelajaran Group Investigation menjadikannya lebih mampu menyampaikan pendapat di dalam kelas $85 \%$ siswa mengatakan metode pembelajaran Group Investigation dapat menumbuhkan kebiasaan cara bekerja yang baik dalam kehidupan sehari-hari.61\% siswa mengatakan bahwa metode pembelajaran Group Investigation dapat meniadakan penyajian yang bersifat verbalitas.

\section{Prestasi siswa sebelum dan sesudah meng- implementasikan metode pembelajaran}

Untuk mengetahui tingkat pemahaman peserta didik dalam penyerapan materi pembelajaran yang disampaikan guru, dilaksanakan dua kali penilaian, penilaian pertama dilakukan sebelum pembelajaran Metode Market Place Activities dimulai (PreTest) dan penilaian kedua setelah pembelajaran Metode Market Place Activities dilaksanakan (Post-Test), kedua Test tersebut dilaksanakan melalui system Digital Quiz dimakan soal yang disampaikan kepada siswa dan jawaban siswa atas pertanyaan dalam test tersebut tidak lagi lagi menggunakan kertas tetapi sudah berbentuk quiz digital dan bisa dilihat dan dijawab melalui laptop atau handphone.

Hasil dari kedua test dengan metode Market Place Activities yang dilakukan di kelas XII IPA 1 sebanyak 33 siswa, pada waktu pre test sebelum siswa menggunakan metode market place activities rata-rata nilai siswa 57,12 dan setelah pembelajaran menggunakan metode Market Place Activities rata-rata nilai siswa 98,36.

Kemudian untuk mengetahui tingkat pemahaman peserta didik dalam penyerapan materi pembelajaran pada metode Expert Group, penilaian pertama dilakukan sebelum pembelajaran Metode Expert Group dimulai (Pre-Test), penilaian kedua setelah pembelajaran Expert Group dilaksanakan (Post-Test), kedua Test tersebut dilaksanakan melalui system Digital Quiz dimakan soal yang disampaikan kepada siswa dan jawaban siswa atas pertanyaan dalam test tersebut tidak lagi lagi menggunakan kertas tetapi sudah berbentuk quiz digital dan bisa dilihat dan dijawab melalui laptop atau handphone.

Hasil dari kedua test dengan metode ekspert group yang dilakukan di kelas XII IPS 1 sebanyak 34 siswa, pada waktu pre test sebelum siswa menggunakan metode ekspert group rata-rata nilai siswa 48,88 dan setelah pembelajaran menggunakan metode ekspert group rata-rata nilai siswa 96,41.

Selanjutnya untuk mengetahui tingkat pemahaman peserta didik dalam penyerapan materi pembelajaran menggunakan metode group infestigation, penilaian dilakukan dua kali juga yaitu penilaian pertama dilakukan sebelum pembelajaran Metode Group Investigation dimulai (Pre-Test), penilaian kedua setelah pembelajaran Group Investigation dilaksanakan (Post-Test), kedua Test tersebut dilaksanakan melalui system Digital Quiz dimakan soal yang disampaikan kepada siswa dan jawaban siswa atas pertanyaan dalam test tersebut tidak lagi lagi menggunakan kertas tetapi sudah berbentuk quiz digital dan bisa dilihat dan dijawab melalui laptop atau handphone.

Hasil dari kedua test dengan metode Group Investigation yang dilakukan di kelas XII IPA 5 sebanyak 32 siswa, pada waktu pre test sebelum siswa menggunakan metode Group Investigatian rata-rata nilai siswa 46,16 dan setelah pembelajaran menggunakan metode group investigationrata-rata nilai siswa 95,59 .

\section{PEMBAHASAN}

Perbandingan rata-rata prestasi belajar siswa sebelum (pre-test) dan setelah (post-test) diterapkan metode pembelajaran market place activities, expert group, dan group investigation pada pelajaran PAI dapat dilihat pada Gambar 1.

Rata-rata prestasi siswa meningkat setelah diterapkan metode pembelajaran Market Place Activities, Expert Group, dan Group Investigation pada pelajaran PAI. Perolehan rata-rata hasil post-test terlihat bahwa prestasi belajar siswa yang diterapkan metode pembelajaran Market Place Activities 
lebih tinggi dibandingkan dengan Expert Group, dan Group Investigation.

Analisis data penelitian ini menggunakan metode statistik Analysis of Varians (ANOVA). ANOVA digunakan untuk menganalisis perbedaan dua atau lebih rata-rata dari kelompok sampel. Dalam penelitian ini ingin melihat perbedaan antara ketiga rata-rata prestasi siswa pada pelajaran PAI setelah diterapkan metode pembelajaran market place activities, expert group, dan group investigation. Analisis data dilakukan menggunakan software SPSS, hasil yang diperoleh adalah dengan jumlah siswa yang menjadi objek eksperimen yaitu sebanyak 99 siswa, diantaranya 33 siswa menggunakan metode pembelajaran MPA, 34 siswa menggunakan metode pembelajaran EG dan 32 siswa menggunakan metode pembelajaran GI.

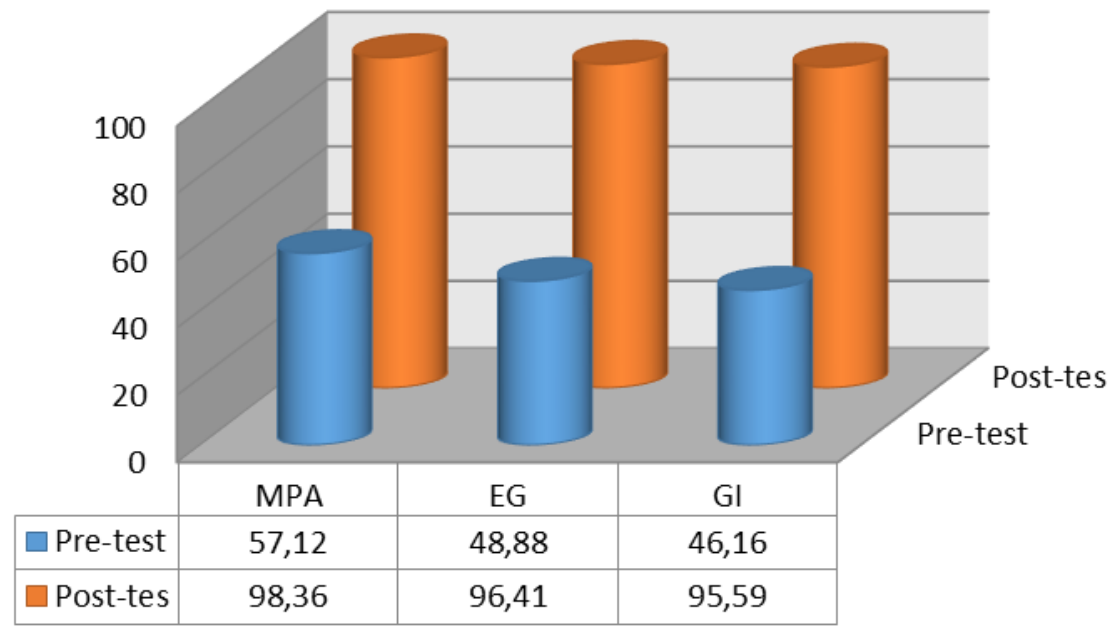

Gambar 1. Perbandingan rata-rata prestasi siswa

Keterangan:

$$
\begin{aligned}
& \text { MPA }=\text { Market Place Activities } \\
& \text { EG }=\text { Expert Group } \\
& \text { GI }=\text { Group Investigation }
\end{aligned}
$$

Sedangkan rata-rata prestasi siswa yang diperoleh setelah menggunakan metode pembelajaran MPA adalah 98,36, setelah menggunakan EG 96,41, dan yang menggunakan metode GI adalah 95.59. Nilai maksimum prestasi siswa yang diperoleh memiliki kesamaan untuk ketiga metode pembelajaran yang diterapkan dengan nilai 100. Sedangkan nilai minimum prestasi siswa yang diperoleh bervariatif untuk ketiga metode pembelajaran yang diterapkan yaitu 86 untuk MPA, 83 untuk EG dan 66 untuk IG.

Data dianalisis menggunakan ANOVA apabila ketiga kelompok data memiliki varians yang sama (homogen). Untuk mengetahui kehomogenan ketiga data maka dilakukan uji homogenitas menggunakan uji Levene Statistic. Hasil analisis uji homogenitas ketiga data adalah sebesar 0,008 (lebih kecil dari nilai $\alpha=0,05$ ) maka dapat disimpulkan ketiga kelompok data memiliki varians yang sama (homogen).

Karena ketiga kelompok data memiliki varians homogeny maka analisis data dilakukan menggunakan ANOVA. Hasil anova yang diperoleh 0,165 lebih besar dari nilai $\alpha=0,05$, maka hipotesis (H0) diterima.

Sehingga dapat disimpulkan bahwa tidak ada perbedaan rata-rata prestasi siswa pada pelajaran PAI yang menggunakan metode pembelajaran MPA, EG ataupun IG.

Selanjutnya apabila pengujianh ipotesis dilakukan secara parsial dengan menggunakan uji Tukey untuk mengetahui perbedaan ratarata prestasi siswa pada pelajaran PAI yang menggunakan metode pembelajaran MPA dan EG, atau MPA dan GI, atau EG dan GI. Berdasarkan hasil uji parsial, diperoleh nilai sig. antara MPA dan EG, MPA dan IG serta EG dan GI, lebih besar dari nilai $\alpha=0,05$, sehingga dapat disimpulkan untuk memperkuat 
hasil yang diperoleh pada tabel ANOVA yaitu tidak ada perbedaan rata-rata prestasi siswa pada pelajaran PAI yang menggunakan metode pembelajaran MPA, EG atau IG.

Perbedaan rata-rata prestasi siswa yang menggunakan metode pembelajaran MPA, EG atau IG dapat di gambarkan dalam grafik (Gambar 2).

Metode pembelajaran Market Place Activities adalah metode pembelajaran yang cocok disampaikan di awal pertemuan, untuk memperkenalkan konsep, memahami prosedur, mengenalkan istilah-istilah yang berkaitan dengan materi pembelajaran, sedangkan metode pembelajaran Expert Group dan Group Investigation sangat baik disampaikan pada pertemuan kedua atau ketiga dimana pada pertemuan tersebut diperlukan penguatanpenguatan terhadap materi pembelajaran.

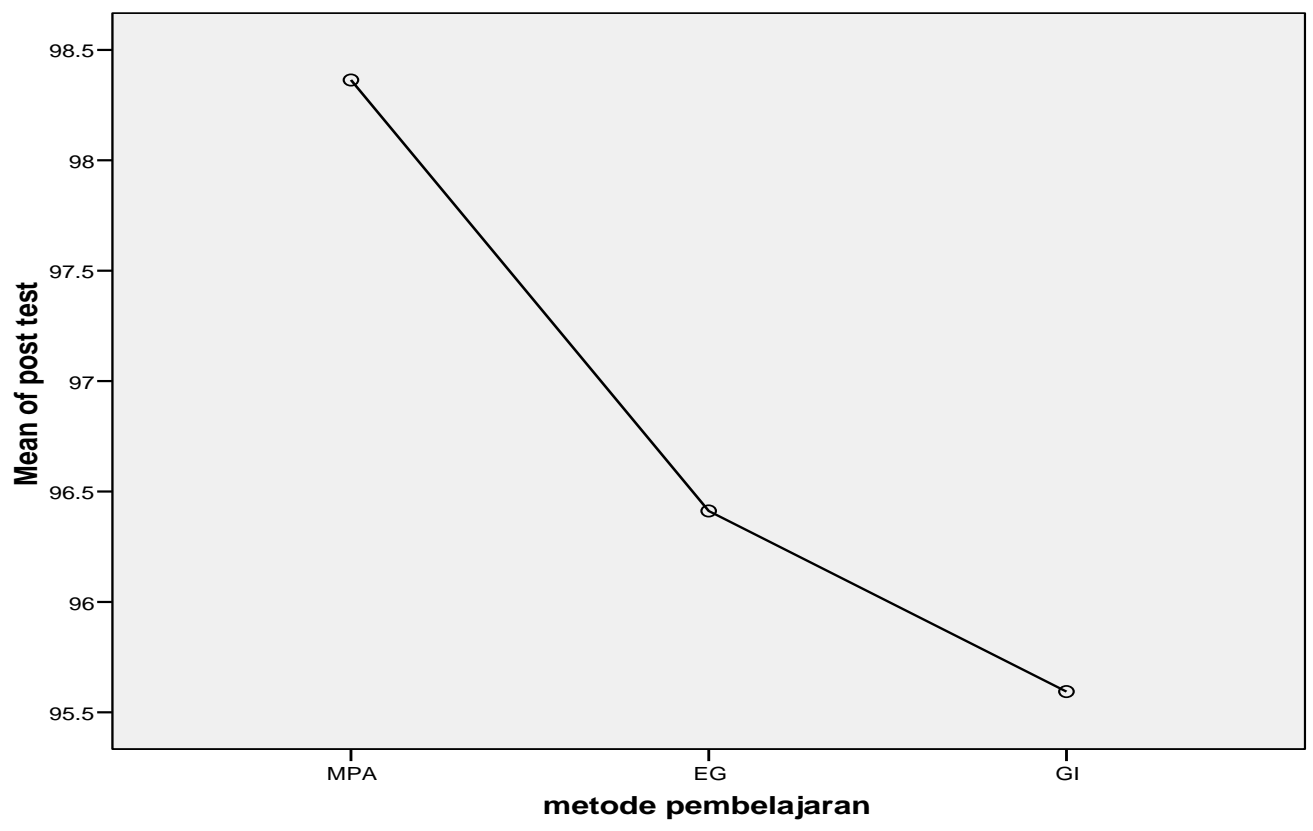

Gambar 2. Perbandingan rata-rata prestasi siswa (post-test) yang menggunakan metode pembelajaran MPA, EG dan GI

\section{Faktor pendukung dan kendala Implementasi}

Dalam proses belajar mengajar factor pendukung dan kendalanya dari ketiga metode tersebut pada dasarnya terdapat kesamaan karena masih dalam satu lembaga dan guru yang mengajar sama, yaitu Pendukung: Guru Model menguasai bagaimana cara mengimplementasikan Metode Pembelajaran Market Place Activities, Expert Group dan Group Investigatian.Para siswa terbiasa menerima pembelajaran melalui penerapan berbagai metode pembelajaran Marketplace Activities, Expert Group dan Group Investigatian, Pihak manajemen sekolah mendorong setiap guru untuk penerapan berbagai metode pembelajaran Market Place Activities, Expert Group dan Group Investigatian dan Sarana prasarana, sumber belajar dan media pembelajaran yang mendukung dalam mengimplementasikan Metode Pembelajaran Market Place Activities bisa diperoleh dengan mudah. Disamping banyak pendukung ada kendala yaitu Kendala tingginya tingkat keikutsertaan para siswa dalam kegiatan lomba-lomba ekstrakurikuler sehingga ada siswa yang tidak hadir pada saat penelitian. Dan banyaknya tamu yang datang ke SMAN 11 Bandung pada saat pelaksanaan implementasikan Metode Pembelajaran sehingga menggangu proses kegiatan tersebut.

\section{PENUTUP}

Metode Market Place Activities, Expert Group, dan Group Investigation pada pembelajaran Pendidikan Agama Islam, telah di implementasikan oleh Guru PAI yang mengikuti pelatihan metode pembelajaran di Oxford, yaitu guru PAI SMA Negeri 11 Bandung dengan baik dan lancar. 
Respon siswa terhadap metode pembelajaran Market Place Activities sangat baik, hal ini dilihat dari seluruh siswa mengatakan metode pembelajaran Market Place Actifities dapat membangkitkan semangat/menambah gairah belajar, dapat mengembangkan kegiatan kepribadian, dapat mewujudkan hasil karya, bisa merangsang belajar lebih lanjut, dapat melakukan eksplorasi dan inovasi, dapat menanamkan sikap-sikap utama yang diharapkan dalam Kurikulum 2013. Adapun terhadap kemudahan materi, pada umumnya siswa mengatakan mudah $93,94 \%$, sangat mudah $3 \%$, dan yang mengatakan sulit hanya $3 \%$.

Respon siswa terhadap metode pembelajaran Expet Group adalah baik, hal ini dilihat dari seluruh siswa mengatakan metode Expet Group lebih mampu menyampaikan pendapatnya di dalam kelas, dapat melakukan eksplorasi dan inovasi, dan bisa menanamkan dan mengembangkan nilai-nilai yang diharapkan. Adapun terhadap tingkat kemudahan materi, seluruh siswa mengatakan mudah.

Respon siswa terhadap metode Pembelajaran Group Investigation juga Baik, Hal ini terlihat dari seluruh siswa mengatakan metode Group investigation dapat mengembangkan kegiatan kepribadian, dapat melakukan eksplorasi dan inovasi, dapat menanamkan sikap-sikap utama yang diharapkan, dapat menumbuhkan kebiasaan cara bekerja yang baik dalam kehidupan sehari-hari. Adapun tingkat kemudahan materi, yang mengatakan sangat mudah $30,30 \%$, mudah $63,63 \%$, sulit $3 \%$ dan sangat sulit $3 \%$.

Ketiga metode pembelajaran (Market Place Activities, Expet Group dan Group Investigation) dapat meningkatkan prestasi siswa. Hal ini dapat dilihat dari hasil uji signifikansi hasil nilai pre tes dan post tes dari tiga metode tersebut sebesar 0,008. Berdasarkan hasil uji Anova ketiga metode pembelajaran tersebut didapatkan hasil angka sig. 0.165, ini menunjukkan tidak ada perbedaan diantara ketiga metode pembelajaran tersebut.

Faktor Pendukung dalam penerapan metode Market Place Activities, Expet Group dan Group Investigation adalah Guru menguasai dalam implementasikan metode pembelajaran, siswa terbiasa menerima pembelajaran melalui penerapan berbagai metode pembelajaran, manajemen sekolah mendorong setiap guru untuk mengembangkan berbagai metode pembelajaran, dan sarana prasarana, sumber belajar dan media pembelajaran mendukung dalam mengimplementasikan metode pembelajaran tersebut. Sedang kendalanya adalah tingginya tingkat keikutsertaan para siswa dalam kegiatan lomba-lomba ekstrakurikuler sehingga ada siswa yang tidak hadir pada saat penelitian.

\section{UCAPAN TERIMA KASIH}

Atas selesainya karya tulis ini, saya menghaturkan terima kasih kepada Kepala Puslitbang Pendidikan Agama dan Keagamaan, Badan Litbang dan Diklat Kementerian Agama RI. yang telah memberikan kesempatan dan dukungan untuk melaksanakan penelitian ini. Kepada tementemen peneliti yang telah membantu kami, kepada narasumber dari Direktorat PAIS yang telah memberi masukan dalam penelitian ini, Kepala Sekolah dan guru PAI pada lembaga sekolah sasaran penelitian, yang telah memberi data-data penelitian. Semoga semuanya mendapatkan ganjaran yang berlipat ganda dari Allah SWT. Amin.

\section{DAFTAR PUSTAKA}

Ginting, Abdurrahman. (2008). Esensi Praktis Belajar dan Pembelajaran, Bandung: Humaniora.

ACDP, Terms of Reference ToT for NATIONAL Trainers on Teaching Methodology of Islamic Religius Education. Implementing patner Directorate of Islamic Education, Directorate General of Islamic Education, Ministry of Religious Affairs. Ahmadi, Abu. Prastya, Joko T. (2005). Strategi Belajar Mengajar. Bandung: CV Pustaka Setia.

Tafsir, Ahmad, (1994). Ilmu Pendidikan Dalam Perspektif Islam, Bandung: PT. Remaja Rosdakarya.

Direktorat Pendidikan Agama Islam, Direktorat Jenderal Pendidikan Islam Kementerian Agama RI, (2015). Modul Metode Pembelajaran, Bimbingan 
Teknis Pembelajaran Pendidikan Agama Islam dan Budi Pekerti berbasis ISRA.

Setiawan Guntur, (2004). Implementasi Dalam

Birokrasi Pembangungan. Jakarta: Cipta Dunia.

Haidar Putra Daulay, (2004). Pendidikan Islam, Jakarta: Kencana.

I.G.N. Agung, (1992). Metode Penelitian Sosial: Pengertian dan Pemakaian Praktis Jilid 1 dan 2, Jakarta: Gramedia.

Lampiran Permendiknas Nomor 41, (2007). Tanggal 23 November 2007 tentang Standar Poses untuk Satuan Pendidikan Dasar dan Menengah.
Lexy J. Maleong, (2008). Metodologi Penelitian Kualitatif, Bandung: Remaja Rosdakarya Offset.

Sugiyono, (2008). Memahami Penelitian Kualitatif, Bandung:Alfabeta.

Usman, Nurdin. (2002). Konteks Implementasi Berbasis Kurikulum. Jakarta: PT. Raja Grafindo Persada.

Wina Sanjaya, (2008). Strategi Pembelajaran Berorientasi Standar Proses Pendidikan Jakarta: Kencana Prenada Media Group. 